\title{
STUDI PENGGUNAAN PLASTIK POLYPROPYLENE PADA CAMPURAN ASPHALT CONCRETE-WEARING COURSE
}

\author{
Tan Lie Ing1), Wildan Reza Pahlevi2) \\ 1) Program Studi Teknik Sipil Universitas Kristen Maranatha, Jl. Prof. drg. Surya Sumantri No. 65, Bandung, Jawa Barat \\ 2) Alumni Program Studi Teknik Sipil Universitas Kristen Maranatha, Jl. Prof. drg. Surya Sumantri No. 65, Bandung, Jawa Barat
}

\begin{abstract}
The quality of implementation, drainage, materials that do not meet the standards, and overloaded from the specified class of roads are the main causes of road damage. Thus violations and negligence both in the implementation or maintenance of the road can cause a lot of traffic accidents, damage to vehicles, and various things that can distrupting the comfort and safety of drivers or pedestrians. The purpose of this study was to evaluate the effect of polypropylene plastic as an additive in the Asphalt Concrete-Wearing Course (AC-WC) layer. The use of polypropylene waste used as an additive is around $2.5 \%$; $3.5 \%$; $4.5 \%$; and $5.5 \%$ of the asphalt weight. Based on the results of the analysis it was concluded that the mixture of AC-WC with the addition of polypropylene plastic experienced increased stability and decreased melting. Polypropylene plastic which can be used based on the five Marshall test parameters with the highest value of stability and lowest melting is $4.5 \%$ of the weight of asphalt.
\end{abstract}

Key Words: Asphalt Concrete-Wearing Course, parameter Marshall, polypropylene

\section{PENDAHULUAN}

Perkerasan jalan merupakan salah satu hal penting untuk memajukan roda ekonomi suatu bangsa. Kualitas pelaksanaan, drainase, bahan atau material yang tidak sesuai, dan kelebihan beban merupakan permasalahan yang terjadi di lapangan sehingga untuk mengatasinya diperlukan inovasi. Sukirman (2003) menyatakan bahwa jalan-jalan dengan keadaan lalu lintas berat biasanya menggunakan asphalt concrete. Lapis aus merupakan salah satu lapisan yang berhubungan langsung dengan beban kendaraan dan gesekan roda kendaraan sehingga lapis aus harus tahan terhadap segala macam kondisi cuaca dan memiliki kekesatan sesuai persyaratan.

Aspal modifikasi dengan menambahkan berbagai jenis aditif berupa polimer menggunakan plastik dari jenis polypropylene (PP) ini sering ditemukan dalam bentuk gelas plastik yang dipakai oleh masyarakat dalam kehidupan sehari-hari. Campuran dengan bahan plastik ini bermaksud untuk meningkatkan berbagai karakteristik aspal non-modifikasi, terutama dalam menaikkan nilai stabilitas (Alexander, 2017).

Maksud penelitian ini adalah untuk menganalisis karakteristik parameter Marshall akibat penggunaan plastik polypropylene pada campuran asphalt concrete-wearing course (AC-WC) menggunakan uji Marshall dan mengacu kepada Spesifikasi Bina Marga 2018. Tujuan penelitian ini adalah mengevaluasi karakteristik Marshall tanpa plastik polypropylene; mengevaluasi karakteristik Marshall dengan adanya penggunaan plastik polypropylene; dan menentukan kadar plastik polypropylene yang dapat digunakan.

\section{TINJAUAN PUSTAKA}

Yayasan Lembaga Konsumen Indonesia (2016) menyatakan bahwa Indonesia merupakan penyumbang terbesar kedua sampah plastik di dunia. Plastik polypropylene dipilih karena bahan relatif mudah didapat dan bahan tidak mengeluarkan asap saat dipanaskan, sehingga relatif lebih aman dan tidak beracun, jika dibandingkan dengan jenis plastik lainnya seperti Polyvinyl Chloride (PVC).

Ruang lingkup dalam penelitian ini adalah:

1. asal bahan/material:
a. agregat kasar,
b. agregat halus,
c. filler abu batu,
d. aspal pen 60 ,
e. plastik jenis polypropylene,

2. metode perancangan yang digunakan sebagai acuan adalah Divisi VI Perkerasan Aspal Departemen Pekerjaan Umum edisi Tahun 2018, Pt T-01-2002 Pedoman Perencanaan Tebal Perkerasan Lentur,

3. pengujian bahan yang dilakukan adalah gradasi agregat, berat jenis aspal, berat jenis agregat, dan viskositas. 
Campuran lapis beton aspal merupakan suatu lapisan pada konstruksi jalan yang terdiri atas campuran aspal keras dan agregat yang mempunyai gradasi menerus, dicampur, dihampar, dan dipadatkan pada temperatur tertentu. Lapis beton aspal memiliki sifat kedap air, mempunyai nilai struktural, awet, mempunyai kadar aspal 4-8\% terhadap berat campuran, dan digunakan untuk lalu lintas ringan, sedang sampai berat. Karakteristik campuran yang harus dimiliki oleh beton aspal adalah stabilitas; ketahanan terhadap kedap air; pelelehan; keawetan; kelenturan; kekesatan; dan mudah dilaksanakan.

Sifat campuran beton aspal ini tidak dapat dipenuhi di dalam satu campuran, sehingga perlu diperhatikan sifat beton aspal untuk menentukan jenis beton aspal. Leily (2012) menyatakan bahwa jalan yang memiliki lalu lintas ringan seperti mobil penumpang seharusnya lebih menggunakan beton aspal yang mempunyai sifat durabilitas tinggi daripada menggunakan beton aspal dengan sifat lainnya. Sifat campuran yang harus dimiliki adalah sesuai dengan jenis laston yang dipilih. Spesifikasi sifat campuran laston yang digunakan adalah sifat campuran asphalt concrete wearing course sesuai persyaratan.

Agregat merupakan suatu bahan keras dan kaku digunakan sebagai bahan campuran berupa berbagai jenis butiran atau pecahan yang termasuk di dalamnya abu (debu) agregat. Agregat merupakan bahan utama dalam suatu campuran karena sekitar 90-95\% berat suatu campuran terdiri atas agregat. Oleh karena itu, agregat merupakan bahan utama penahan beban yang diterima oleh perkerasan dengan bantuan aspal sebagai bahan pengikat. Agregat terdiri atas beberapa jenis yaitu: agregat kasar, agregat halus, dan bahan pengisi.

Agregat memiliki beberapa kriteria sifat dasar agar dapat dipergunakan sebagai material pada perkerasan jalan. Sifat-sifat yang perlu dimiliki agregat, salah satunya adalah gradasi agregat. Gradasi adalah susunan butir agregat sesuai ukurannya. Ukuran butir agregat dapat diperoleh melalui pemeriksaan analisis ayakan. Satu set ayakan umumnya terdiri atas ayakan berukuran 4 inci, $3 \frac{1}{2}$ inci, 3 inci, $2 \frac{1}{2}$ inci, 2 inci, 11/2 inci, $3 / 4$ inci, $1 / 2$ inci, $3 / 8$ inci, No.4, No.8, No.16, No.30, No.50, No.100 dan No.200. Ukuran ayakan dalam ukuran panjang menunjukkan banyaknya bukaan dalam 1 inci panjang.

Gradasi agregat diperoleh dari hasil analisis pemeriksaan dengan mempergunakan 1 set ayakan. Ayakan berukuran bukaan paling besar diletakkan paling atas dan paling halus (No.200) diletakkan paling bawah sebelum pan. Aspal seringkali dianggap sebagai bahan lapisan permukaan jalan yang bertanggung jawab terhadap kerusakan jalan.
Sebagai salah satu bahan konstruksi jalan, aspal tidak akan terlepas dari keterkaitannya dengan bahan utama konstruksi perkerasan lainya yaitu agregat. Selain aspal, ada juga tar dan pitch yang didapatkan dari hasil produk kimiawi dan tidak didapatkan dari alam

Polypropylene adalah polimer dengan penggunaan terbesar ketiga di dunia setelah PE dan PVC. Polypropylene (PP) memiliki rumus kimia (C3H6)x. Kebanyakan polypropylene komersial merupakan isostatik dan memiliki kristalinitas tingkat menengah di antara polietilena berdensitas rendah dengan polietilena berdensitas tinggi.

Polypropylene atau polipropena (PP) merupakan sebuah polimer termo plastik yang dibuat oleh industri kimia dan digunakan dalam berbagai aplikasi, di antaranya: pengemasan, tekstil (contohnya tali, pakaian dalam termal, dan karpet), alat tulis, berbagai tipe wadah alat-alat rumah tangga yang dapat dipakai kembali (contohnya ember plastik, gelas plastik, toples, dan lain-lain), perlengkapan laboratorium, pengeras suara, komponen otomotif, dan uang kertas polimer.

Polimer adisi yang terbuat dari propilena monomer, permukaannya tidak rata serta memiliki sifat resistan yang tidak tahan terhadap pelarut kimia seperti basa dan asam. Polipropilena biasanya dapat didaur ulang. Nurminah (2002) menjelaskan PP merupakan film yang lunak, transparan, fleksibel, mempunyai kekuatan benturan serta kekuatan sobek yang baik. PP dengan pemanasan akan menjadi lunak dan mencair pada temperatur $150^{\circ} \mathrm{C}$.

Polypropylene mempunyai kombinasi sifat-sifat: kekuatan (strength) yang tinggi, kaku (stiffness), dimensinya stabil, tahan bahan kimia dan panas serta mempunyai sifat elektrikal yang baik. PP memiliki daya serap uap yang rendah, demikian juga daya serap terhadap air. PP dapat diproses dengan proses ekstrusi (pelelehan) pada temperatur tinggi $150^{\circ} \mathrm{C}$. Selain itu, juga dapat diproses dengan teknik cetak injeksi maupun cetak tiup. Mujiarto (2005) menyatakan bahwa botol-botol dari PP dapat dibuat lebih tipis daripada PE karena lebih kuat.

Penelitian-penelitian tentang pengunaan plastik polypropylene (PP) sebagai bahan tambah (additive) terhadap campuran laston yang pernah dilakukan oleh beberapa peneliti dan dapat dijadikan acuan atau literatur dalam penelitian ini di antaranya:

1. Rahmawati (2013) menyatakan pengaruh penggunaan limbah plastik polipropilena sebagai pengganti agregat pada campuran laston terhadap karakteristik Marshall diperoleh nilai stabilitas, VIM, QM meningkat dan density, VFA, dan flow cenderung menurun;

2. Al-Hadidy dan Tan (2009) menyatakan penambahan polypropylene memberikan tambahan kekuatan atau ketahanan (stabilitas) 
perkerasan jalan sebesar $46,7 \%$ pada penambahan sebesar 5\% (10,876 KN) dibandingkan perkerasan jalan tanpa PP yang memiliki stabilitas sebesar $7,412 \mathrm{KN}$;

3. Tapkin (2008) menyatakan terjadi peningkatan angka stabilitas sebesar $58 \%$ pada penambahan serat polypropylene sebesar $0,3 \%$, yakni dari 1541 $\mathrm{kg}$ menjadi $2108 \mathrm{~kg}$;

4. Shankar, A U Ravi, et. al (2013), dalam judul "Performance Studies on Bituminous Concrete Mixes using Waste Plastics" menjelaskan bahwa nilai stabilitas Marshall pada campuran plastik 6\% lebih tinggi dibandingkan dengan campuran lainnya. Flow, VIM, dan VFA juga mengalami peningkatan, limbah plastik sangat baik untuk perkerasan lentur karena plastik dapat mencair pada temperatur tertentu dan berfungsi sebagai filler.

Perencanaan campuran diperlukan untuk mendapatkan campuran yang memenuhi spesifikasi. Metode perencanaan campuran yang biasa dipergunakan di Indonesia adalah metode Bina Marga.

\section{METODOLOGI}

Metode yang dilakukan dalam melaksanakan penelitian ini adalah metode eksperimental di laboratorium. Bahan-bahan yang digunakan dalam penelitian ini adalah kerikil dan pasir dari Lagadar, plastik polypropylene, dan bahan aspal menggunakan aspal penetrasi 60. Peralatan yang digunakan dalam pengujian adalah:

1) alat yang digunakan pada pengujian aspal, yaitu piknometer, dan timbangan;

2) alat yang digunakan pada pengujian agregat, yaitu satu set ayakan (1", 3/4", 1/2", 3/8", No.4, No.8, No.12, No.16, No.30, No.50, No.100, dan No.200), wadah pengaduk, oven, piknometer, timbangan, dan pemanas;

3) alat uji karakteristik campuran beraspal, yaitu menggunakan seperangkat alat uji Marshall, yaitu alat Marshall Compactor dan alat uji Marshall;

4) alat tekan Marshall yang terdiri atas kepala penekan berbentuk lengkung, cincin penguji berkapasitas $2500 \mathrm{~kg}(5000 \mathrm{lb})$, dan dilengkapi dengan arloji pelelehan;

5) alat cetak benda uji yang berdiameter $10,2 \mathrm{~cm}(4$ inci) dan tinggi $7,5 \mathrm{~cm}$ (3 inci) lengkap dengan pelat alas;

6) penumbuk yang mempunyai permukaan tumbuk rata berbentuk silinder dengan berat 4,5 $\mathrm{kg}(10,11$ lb) dan tinggi jatuh bebas $45,7 \mathrm{~cm}$ (18 inci);

7) ejektor untuk mengeluarkan benda uji setelah proses pemadatan;

8) bak perendam dilengkapi dengan pengatur temperatur;
9) perlengkapan lain yang meliputi pemanas, timbangan, wadah pencampuran, sendok pengaduk, lap, sarung tangan, termometer, spatula, spidol, dan tip-ex untuk menandai benda uji.

Sebelum melakukan pencampuran pembuatan benda uji, hal pertama yang dilakukan adalah menghitung kadar aspal yang menjadi acuan untuk membuat benda uji Marshall agar diperoleh kadar aspal optimum.

\section{A. Mencari kadar aspal optimum}

1. Berdasarkan perkiraan kadar aspal rencana, yaitu $5 \% ; 5,5 \% ; 6 \% ; 6,5 \% ; 7 \%$, dibuat 3 benda uji untuk masing-masing kadar aspal. Total benda uji untuk mendapatkan kadar aspal optimum adalah 15 benda uji.

2. Setiap benda uji diperlukan agregat sebanyak \pm 1100 gr dengan diameter 4 inci. Panaskan wadah pencampuran beserta agregat kira-kira $30^{\circ} \mathrm{C}$ di atas temperatur pencampuran $\left(170^{\circ} \mathrm{C}\right)$. Sementara itu panaskan juga aspal sampai temperatur pencampuran $\left(120^{\circ} \mathrm{C}\right)$.

3. Kemudian tuangkan aspal sebanyak yang dibutuhkan ke dalam wadah yang sudah dipanaskan tersebut. Aduk sampai merata.

4. Dilakukan tes kompaksi uji Marshall standar dengan 2 x 75 tumbukan untuk semua benda uji.

5. Benda uji yang telah dikompaksi akan didiamkan hingga mengeras selama \pm 24 jam.

6. Kemudian lakukan uji Marshall untuk mendapatkan kadar aspal optimum dan parameter Marshall, yaitu: VIM, VMA, VFA, stabilitas, pelelehan, dan lainnya sesuai dengan spesifikasi campuran. Langkah-langkah uji Marshall yaitu:

a. dilakukan penimbangan berat kering terlebih dahulu. Kemudian rendam benda uji selama 20 menit dan timbang berat benda uji dalam air. Ditimbang lagi pada kondisi kering permukaan jenuh. Rendam benda uji dalam bak perendam selama 30 menit pada temperatur $(60 \pm 1)^{\circ} \mathrm{C}$. Keluarkan benda uji dari bak perendam dan letakkan ke dalam segmen bawah kepala penekan. Waktu yang diperlukan pada saat diangkatnya benda uji dari rendaman air tidak boleh melebihi 30 detik. Pasang segmen atas di atas benda uji dan letakkan keseluruhannya dalam mesin penguji. Pasang arloji pelelehan pada kedudukannya di atas salah satu batang penuntun dan atur kedudukan jarum penunjuk angka nol. Sementara itu, tekan selubung tangkai arloji pelelehan tersebut pada segmen atas dari kepala penekan selama pembebanan berlangsung;

b. berikan pembebanan kepada benda uji dengan kecepatan tetap sebesar $50 \mathrm{~mm}$ per menit 
sampai pembebanan maksimum tercapai atau arloji pelelehan pada saat pembebanan maksimum dan catat nilai pelelehan yang ditunjukkan oleh jarum arloji pelelehan. Dari hasil tesebut akan diperoleh kadar aspal optimum dengan menggambarkan grafik hubungan antara kadar aspal dengan parameter Marshall;

c. dari pelaksanaan pengujian didapat kadar aspal non polypropylene optimum sebesar $6,2 \%$.

\section{B. Evaluasi pengaruh plastik polypropylene dengan kadar aspal optimum}

Kadar aspal optimum yang diperoleh kemudian digunakan untuk mendapatkan hasil perbandingan antara penggunaan $0 \%$ plastik polypropylene dan $2,5 \% ; 3,5 \% ; 4,5 \% ; 5,5 \%$ campuran yang ditambah plastik polypropylene dari berat aspal. Dibuat 3 benda uji untuk masing-masing kadar plastik polypropylene dengan kadar aspal optimum, dengan total 15 benda uji. Diperoleh parameter Marshall berupa VIM, VMA, VFA, dan parameter lainnya menghasilkan kurva perbandingan antara kadar aspal dan parameter tersebut. Langkah-langkah pengujian Marshall sama dengan kadar aspal optimum non plastik polypropylene.

Sjamsudin, Kepala Pusat Penelitian dan Pengembangan Jalan dan Jembatan (2017) menyatakan bahwa perkiraan penggunaan limbah plastik dapat mencapai 5-6\% dari kadar aspal, maka digunakan $0 \% ; 2,5 \% ; 3,5 \% ; 4,5 \%$; dan $5,5 \%$ yang dibuat 12 benda uji dengan masing-masing 3 sampel untuk setiap persennya.

Setiap benda uji memerlukan agregat sebanyak \pm 1100 gr dengan diameter 4 inci. Panaskan wadah pencampuran beserta agregat kira-kira $30^{\circ} \mathrm{C}$ di atas temperatur pencampuran $\left(170^{\circ} \mathrm{C}\right)$. Sementara itu panaskan juga aspal sampai temperatur pencampuran $\left(120^{\circ} \mathrm{C}\right)$.

Kemudian tuangkan aspal yang telah dicampur plastik polypropylene sebanyak yang dibutuhkan ke dalam wadah yang sudah dipanaskan dan aduk sampai merata. Dilakukan tes kompaksi uji Marshall standar dengan $2 \times 75$ tumbukan untuk semua benda uji. Benda uji yang telah dikompaksi akan didiamkan hingga mengeras selama \pm 24 jam. Kemudian lakukan uji Marshall untuk mendapatkan parameter Marshall, yaitu: VIM, VMA, VFA, stabilitas, pelelehan, dan lainnya sesuai dengan spesifikasi campuran.

\section{Polypropylene}

Berdasarkan Badan Pengawas Obat dan Makanan (2009) dan Mujiarto (2005), polypropylene dapat melunak pada temperatur $140^{\circ} \mathrm{C}-160^{\circ} \mathrm{C}$, sehingga pada penelitian ini polypropylene dilelehkan pada temperatur $150^{\circ} \mathrm{C}$.
Diagram alir penelitian dapat dilihat pada Gambar 1.

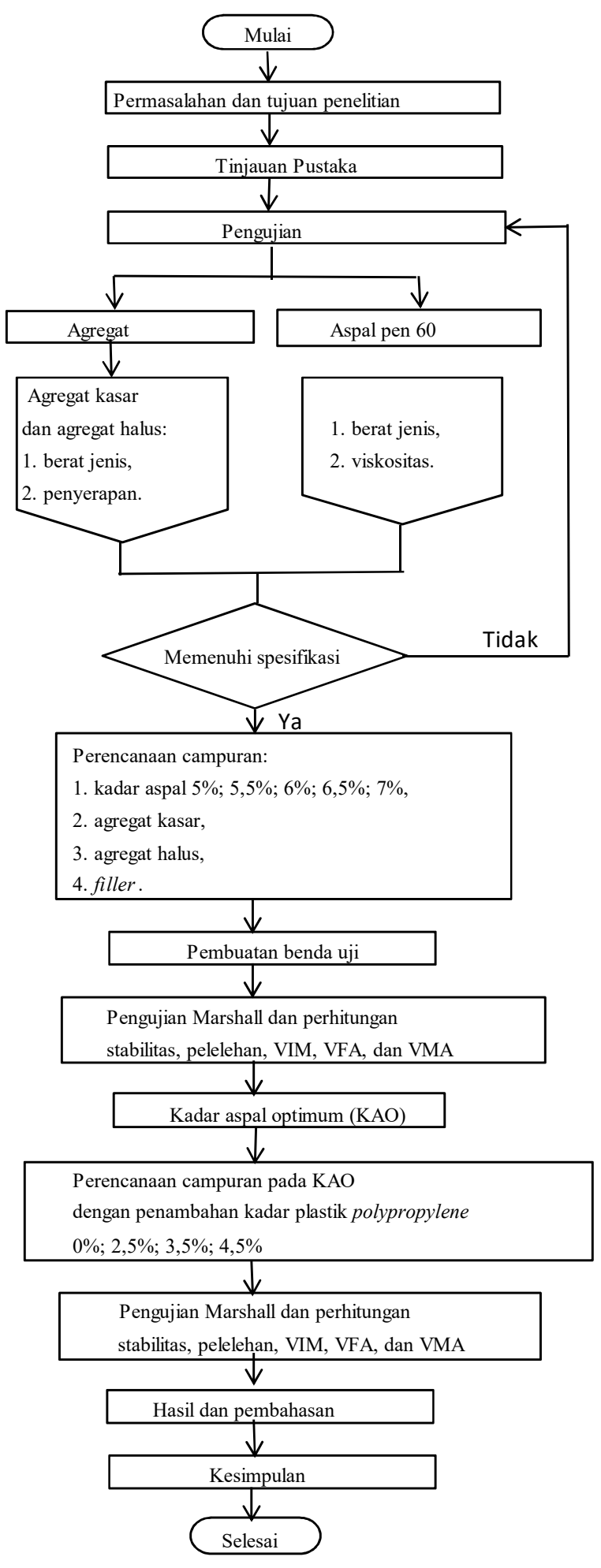

Gambar 1. Diagram Alir Penelitian 


\section{HASIL DAN PEMBAHASAN}

a. Pengujian aspal

Pengujian aspal dilakukan untuk mengetahui sifat fisik dan kimiawi aspal. Pengujian berat jenis untuk mengukur berat jenis aspal menggunakan piknometer dengan perbandingan berat di udara dan berat di dalam air. Berat jenis aspal yang diperoleh sebesar 1,035, berarti aspal yang digunakan memenuhi spesifikasi (persyaratan menurut SNI 2441:2011).

b. Pengujian agregat kasar

Pengujian berat jenis agregat dilakukan untuk mengekspresikan nilai kerapatan/density agregat. Nilai kerapatan agregat diperoleh dengan mengalikan nilai berat jenis agregat dengan kerapatan air pada temperatur standar yang dipakai untuk pengukuran. Hasil pengujian agregat kasar memenuhi standar pengujian.

c. Pengujian agregat halus bertujuan untuk mengetahui sifat fisik dan kimiawi agregat halus. Hasil pengujian agregat halus memenuhi standar pengujian.

d. Penentuan kadar aspal rencana

Fraksi agregat kasar, agregat halus, bahan pengisi digunakan untuk menentukan kadar aspal rencana. Kadar aspal rencana yang diperoleh dapat dilihat pada Tabel 1 .

Tabel 1. Kadar Aspal Rencana

\begin{tabular}{lllll}
\hline \multicolumn{2}{l}{ Batas bawah } & $\mathrm{Pb}_{\mathrm{b}}$ & \multicolumn{2}{l}{ Batas atas } \\
\hline$-1 \%$ & $-0,5 \%$ & $\mathrm{~Pb}$ & $+0,5 \%$ & $+1 \%$ \\
$5 \%$ & $5,5 \%$ & $6 \%$ & $6,5 \%$ & $7 \%$ \\
\hline
\end{tabular}

e. Hasil pengujian Marshall pada kadar aspal rencana. Rata-rata hasil pengujian Marshall pada kadar aspal rencana dapat dilihat pada Tabel 2.

Tabel 2. Rata-rata Hasil Pengujian Marshall pada Kadar Aspal Rencana

\begin{tabular}{rccccr}
\hline \multirow{5}{*}{$\begin{array}{c}\text { Kadar } \\
\text { aspal }\end{array}$} & $\begin{array}{c}\text { VMA } \\
\mathbf{( \% )}\end{array}$ & $\begin{array}{c}\text { VIM } \\
\mathbf{( \% )}\end{array}$ & $\begin{array}{c}\text { VFA } \\
(\mathbf{\%})\end{array}$ & $\begin{array}{c}\text { Stabilitas } \\
(\mathbf{k g})\end{array}$ & $\begin{array}{c}\text { Pelelehan } \\
(\mathbf{m m})\end{array}$ \\
\hline $5 \%$ & 16,055 & 5,145 & 67,954 & 1232,375 & 2,767 \\
$5,50 \%$ & 16,756 & 5,021 & 69,734 & 1438,338 & 3,233 \\
$6 \%$ & 16,82 & 4,565 & 72,861 & 1496,109 & 3,5 \\
$6,50 \%$ & 17,019 & 4,057 & 76,162 & 1387,946 & 3,8 \\
$7 \%$ & 17,265 & 3,602 & 79,136 & 1357,054 & 4,133 \\
\hline
\end{tabular}

Dari Tabel 2, dapat disimpulkan bahwa stabilitas tertinggi terdapat pada kadar aspal 6\% yaitu sebesar 1496,109 kg. Parameter Marshall untuk VIM yang lolos syarat terdapat pada kadar aspal $6 \%$; 6,5\%; dan 7\% yaitu sebesar 4,565\%; $4,057 \%$; dan 3,602\%. Parameter Marshall untuk VMA semua sampel memenuhi syarat yaitu berada di atas $15 \%$. Parameter Marshall VFA semua sampel memenuhi syarat yaitu berada di atas $65 \%$. Setelah mendapatkan seluruh parameter Marshall pada kadar aspal rencana, selanjutnya akan dianalisis menggunakan Gambar 2 sampai dengan Gambar 6 untuk mendapatkan nilai kadar aspal optimum seperti pada Tabel 3.

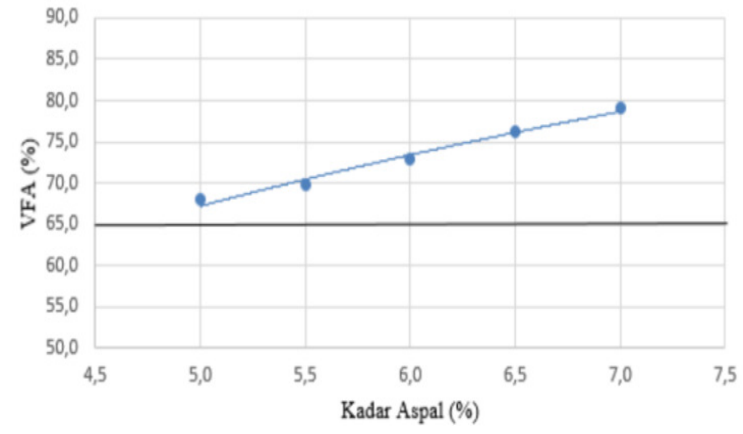

Gambar 2. Hubungan VFA dengan Kadar Aspal

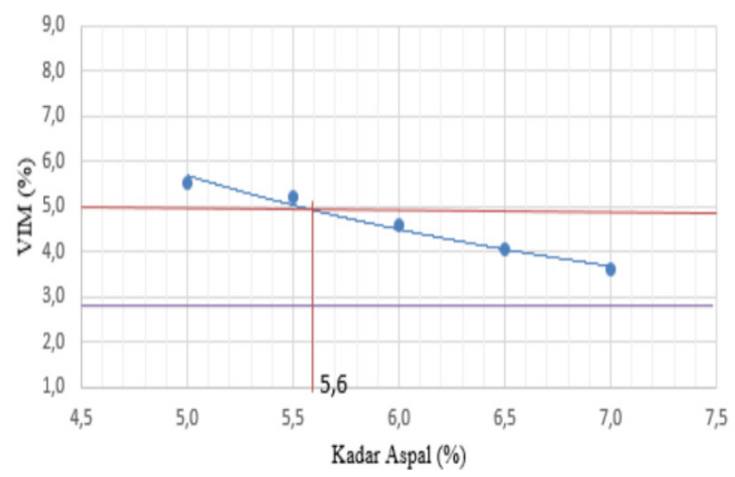

Gambar 3. Hubungan VIM dengan Kadar Aspal

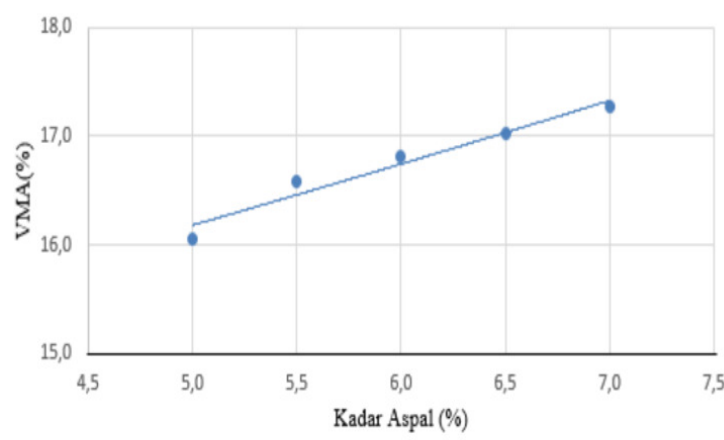

Gambar 4. Hubungan VMA dengan Kadar Aspal

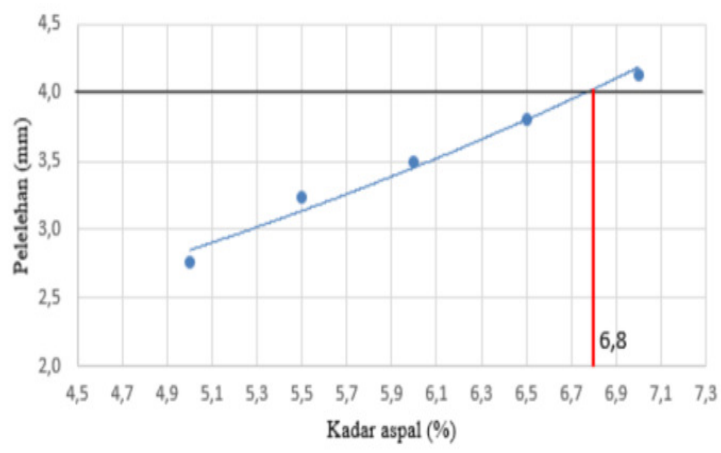

Gambar 5. Hubungan Pelelehan dengan Kadar Aspal 


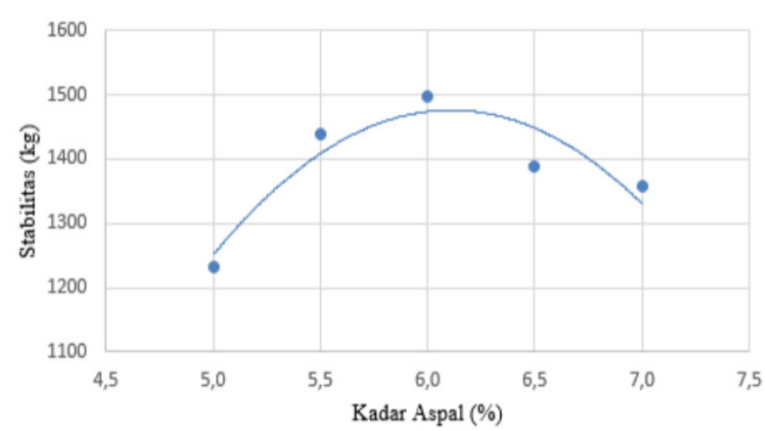

Gambar 6. Hubungan Stabilitas dengan Kadar Aspal

Tabel 3. Penentuan Kadar Aspal Optimum

\begin{tabular}{|c|c|c|c|c|c|}
\hline \multirow{2}{*}{$\begin{array}{l}\text { Parameter } \\
\text { Marshall }\end{array}$} & \multicolumn{5}{|c|}{ Rentang Kadar Aspal yang Memenuhi Spesifikasi } \\
\hline & 5 & 5,5 & 6 & 6,5 & 7 \\
\hline \multicolumn{6}{|l|}{ Stabilitas } \\
\hline \multirow{2}{*}{\multicolumn{6}{|c|}{ Pelelehan }} \\
\hline VMA & & & & & \\
\hline VIM & & & & & \\
\hline VFA & & & & & \\
\hline
\end{tabular}

Berdasarkan hubungan kadar aspal dengan VIM, dapat disimpulkan bahwa untuk kadar aspal 5,6\% sampai 7\% lolos persyaratan. Berdasarkan hubungan kadar aspal dengan VMA, dapat disimpulkan bahwa nilai VMA pada kadar aspal $5 \%$ hingga $7 \%$ lolos persyaratan. Berdasarkan hubungan kadar aspal dengan VFA, dapat dilihat bahwa nilai VFA mempunyai nilai minimum sebesar 65\%, sehingga kadar aspal 5\% sampai $7 \%$ lolos persyaratan. Berdasarkan hubungan kadar aspal dengan pelelehan, dapat disimpulkan bahwa pelelehan pada kadar aspal 5\% hingga $6,8 \%$ memenuhi spesifikasi. Berdasarkan hubungan kadar aspal dengan stabilitas, dapat disimpulkan bahwa semua sampel memenuhi standar yaitu di atas $800 \mathrm{~kg}$. Berdasarkan Tabel 3 , dapat disimpulkan bahwa rentang parameter Marshall yang memenuhi syarat menghasilkan kadar aspal optimum sebesar $6,2 \%$.

f. Hasil pengujian Marshall pada kadar aspal optimum

Kadar aspal optimum yang telah didapatkan kemudian digunakan untuk pengujian Marshall selanjutnya terhadap jenis campuran dengan bahan tambahan. Uji Marshall yang dilakukan menggunakan pengujian $2 \times 75$ tumbukan sesuai spesifikasi. Nomor benda uji dibagi berdasarkan komposisi campuran polypropylene, nomor benda uji 1 mewakili komposisi campuran $0 \%$ polypropylene dari berat total campuran dengan kadar aspal optimum, nomor benda uji 2 mewakili komposisi campuran 2,5\% polypropylene dari berat aspal, nomor benda uji 3 mewakili komposisi campuran 3,5\% polypropylene dari berat aspal, nomor benda uji 4 mewakili komposisi campuran 4,5\% polypropylene dari berat aspal, nomor benda uji 5 mewakili komposisi campuran 5,5\% polypropylene dari berat aspal. Rata-rata hasil pengujian Marshall pada kadar aspal optimum dapat dilihat pada Tabel 4.

Tabel 4. Rata-rata Hasil Pengujian Marshall pada Kadar Aspal Optimum

\begin{tabular}{llllll}
\hline \multirow{2}{*}{$\begin{array}{l}\text { Kadar } \\
\text { polypropylene }\end{array}$} & \multicolumn{5}{l}{ Parameter Marshall } \\
\cline { 2 - 6 } & $\begin{array}{l}\text { VMA } \\
(\%)\end{array}$ & $\begin{array}{l}\text { VIM } \\
(\%)\end{array}$ & $\begin{array}{l}\text { VFA } \\
(\%)\end{array}$ & $\begin{array}{l}\text { Stabilitas } \\
(\mathrm{kg})\end{array}$ & $\begin{array}{l}\text { Pelelehan } \\
(\mathrm{mm})\end{array}$ \\
\hline $0,0 \%$ & 17,632 & 5,039 & 71,423 & $1.408,593$ & 3,79 \\
$2,5 \%$ & 17,162 & 4,498 & 73,796 & $1.466,936$ & 3,71 \\
$3,5 \%$ & 16,797 & 4,076 & 75,734 & $1.533,616$ & 3,50 \\
$4,5 \%$ & 16,432 & 3,655 & 77,774 & $1.653,591$ & 3,21 \\
$5,5 \%$ & 15,688 & 2,798 & 82,166 & $1.699,854$ & 2,83 \\
\hline
\end{tabular}

Dari Tabel 4, dapat disimpulkan parameter Marshall untuk VMA semua sampel memenuhi syarat yaitu minimum 15\%. Parameter Marshall untuk VIM sampel 2,5\%, 3,5\%, dan 4,5\% memenuhi syarat yaitu minimum $3 \%$ dan maksimum $5 \%$. Parameter Marshall untuk VFA semua sampel memenuhi syarat yaitu minimum 65\%. Parameter Marshall untuk pelelehan juga memenuhi syarat yaitu minimum $2 \%$ dan maksimum $4 \%$. Parameter Marshall untuk stabilitas juga memenuhi syarat yaitu minimum $800 \mathrm{~kg}$.

Setelah mendapatkan seluruh parameter Marshall pada kadar aspal rencana, selanjutnya akan dianalisis hubungan kadar polypropylene dengan parameter Marshall. Berdasarkan nilai VIM dapat disimpulkan bahwa nilai VIM pada kadar polypropylene 2,5\% sampai 4,5\% lolos persyaratan. Penambahan polypropylene menurunkan nilai VIM seiring bertambahnya kadar polypropylene yang ditambahkan. Berdasarkan nilai VMA dengan kadar polypropylene dapat disimpulkan bahwa semua sampel lolos persyaratan. Penambahan polypropylene menurunkan nilai VMA seiring bertambahnya kadar polypropylene yang ditambahkan. Berdasarkan nilai VFA dengan kadar polypropylene dapat disimpulkan bahwa nilai VFA semua sampel lolos persyaratan. Penambahan polypropylene meningkatkan nilai VFA seiring bertambahnya kadar polypropylene yang ditambahkan. Berdasarkan hubungan kadar polypropylene dengan pelelehan dapat disimpulkan bahwa nilai pelelehan semua sampel lolos persyaratan. Penambahan polypropylene menurunkan nilai pelelehan seiring bertambahnya polypropylene yang ditambahkan. Berdasarkan hubungan kadar polypropylene dengan stabilitas dapat disimpulkan bahwa nilai stabilitas semua sampel lolos persyaratan. Nilai stabilitas ditentukan berdasarkan material pada campuran beton aspal. 


\section{KESIMPULAN}

Berdasarkan hasil analisis dan pembahasan pengujian di laboratorium, diperoleh kesimpulan sebagai berikut:

1. Campuran AC-WC non polypropylene dengan kadar aspal optimum menghasilkan nilai VMA 17,632\%; VIM 5,039\%; VFA 71,423\%; stabilitas $1408,593 \mathrm{~kg}$; dan pelelehan $3,79 \mathrm{~mm}$;

2. Campuran AC-WC dengan kadar aspal optimum dan penambahan polypropylene adalah:

a. Penambahan 2,5\% polypropylene menghasilkan nilai VMA 17,162\%; VIM 4,498\%; VFA 73,796\%; stabilitas 1466,936 $\mathrm{kg}$; dan pelelehan $3,71 \mathrm{~mm}$;

b. Penambahan $3,5 \%$ polypropylene menghasilkan nilai VMA 16,797\%; VIM 4,076\%; VFA 75,734\%; stabilitas 1533,616 $\mathrm{kg}$; dan pelelehan $3,5 \mathrm{~mm}$;

c. Penambahan $\quad 4,5 \%$ polypropylene menghasilkan nilai VMA 16,432\%; VIM $3,655 \%$; VFA 77,774\%; stabilitas 1653,591 $\mathrm{kg}$; dan pelelehan $3,21 \mathrm{~mm}$;

d. Penambahan 5,5\% polypropylene menghasilkan nilai VMA $15,688 \%$; VIM 2,798\%; VFA 82,166\%; stabilitas 1699,854 $\mathrm{kg}$; dan pelelehan $2,83 \mathrm{~mm}$;

3. Penambahan plastik polypropylene yang dapat digunakan pada kadar $2,5 \%$ polypropylene sampai dengan $4,5 \%$ polypropylene. Jika dilihat dari nilai stabilitas tertinggi dan pelelehan terendah, maka kadar plastik polypropylene yang dapat digunakan adalah $4,5 \%$ dari berat aspal.

\section{REFERENSI}

Alexander, H.B. (2017). Uji Coba Aspal Plastik, Stabilitas Jalan Lebih Kuat 40 Persen, Kompas, http://properti.kompas.com/read/2017/07/29/235336921/ uji-coba-aspalplastik-stabilitas-jalan-lebih-kuat-40persen-, diakses 28 Januari 2019.

Al-Hadidy, A. I. \& Tan, Y. Q. (2009). Mechanistic approach for polypropylene-modified flexible pavement. Material and Design, 30(4), 1133-1140.

Anonim (1995). Mix Design Method, Manual Series-2, Sixth Edition. USA: The Asphalt Institute.

Badan Standardisasi Nasional (2011). SNI 2441:2011, Cara Uji Berat Jenis Aspal Keras. Jakarta: Badan Penelitian dan Pengembangan Kementerian Pekerjaan Umum.

Departemen Pemukiman dan Prasarana Wilayah (2002). Pt T01-2002-B, Pedoman Perencanaan Tebal Perkerasan Lentur.

Kementerian Pekerjaan Umum dan Perumahan Rakyat (2018). Spesifikasi Umum 2018, Jakarta: Direktorat Jenderal Bina Marga.

Mujiarto, I. (2005). Sifat dan Karakteristik Material Plastikdan Bahan Aditif. Jurnal Traksi 3(2). 11-17, Desember 2005.

Rahmawati, A. (2013). Pengaruh Penggunaan Limbah Plastik Polipropilena Sebagai Pengganti Agregat pada Campuran Laston terhadap Karakteristik Marshall (150M). Konferensi Nasional Teknik Sipil ke-7, Universitas Sebelas Maret, Surakarta.

Shankar, A U Ravi, Koushik, K., \& Sarang, G. (2013). Performance studies on bituminous concrete mixes using waste plastics. Highway Research Journal, 6(1), 1-11

Sukirman, S. (2003). Beton Aspal Campuran Panas, Granit, Jakarta.

Tapkin, S. (2008). The effect of polypropylene fibers on asphalt performance. Build. Environ., 43, 1065-1071.

Universitas Kristen Maranatha (2015). Pedoman Praktikum Bahan Perkerasan Jalan. Bandung: Laboratorium Transportasi Fakultas Teknik Jurusan Teknik Sipil.

Yayasan Lembaga Konsumen Indonesia (2016). Indonesia Penunjang Sampah Plastik Terbesar Ke-dua Dunia, hhtp://www.cnnindonesia.com/gaya-hidup/2016. 